\title{
Organising Levels of Organisation for Biology Education: A Systematic Review of Literature
}

\author{
Niklas Schneeweiß * and Harald Gropengießer \\ Institute for Science Education, Leibniz Universität Hannover, 30419 Hannover, Germany \\ * Correspondence: schneeweiss@idn.uni-hannover.de; Tel.: +49-511-7621-8809
}

Received: 8 July 2019; Accepted: 31 July 2019; Published: 5 August 2019

\begin{abstract}
Many authors suggest an explicit reflection on the levels of organisation, based on known difficulties related to understanding biological systems. Yet, there is no scientific consensus on the characteristics of biological levels and the quality of their relationships. This review intends to present the state of the current discussion in order to establish an educational argumentation as a basis for the development of learning environments and teaching experiments in biology education. For this purpose, we conducted a systematic literature review. Three databases (BIOSIS, ERIC, Fachportal-Pädagogik) were searched for literature on levels of organisation. The papers were analysed by means of a qualitative content analysis based on the following research questions: (1) Which levels of organisation do the authors name? (2) How do the authors describe the levels of organisation? (3) How do the authors describe the relationship between different levels of organisation? (4) How do the authors describe the challenges of these levels for biological education? (5) How do the authors describe the benefit of these levels for biological education? Based on the results, we propose a system of levels that features the concept of zooming-in and makes the relationships between the levels explicit.
\end{abstract}

Keywords: biology; systems thinking; levels of organisation; review of literature; teaching; teaching experiments

\section{Introduction}

"Systems thinking has become synonymous to developing coherent understanding of complex biological processes and phenomena from the molecular level to the level of ecosystems". [1] (p. 1)

A crucial part of systems thinking is identifying parts, processes, and their relationship to each other [2]. On the one hand, levels of organisation support the conceptual separation of nested systems, and on the other hand, explanations of biological phenomena require certain levels [3]. Despite the importance of levels, scientists and students use levels differently.

When explaining a scientific phenomenon, scientists often implicitly jump between biological levels. As shown in the quote from the renowned university botanic textbook Strasburger [4], they switch between the organismic, organic, and cellular level: "Small herbaceous plants and delicate organs of bigger plants (leaves, blossoms, fleshy fruits) owe their limited strength to the interplay of turgor and wall pressure (turgescence). This becomes obvious when plants wilt" (p. 87; translated into English). These implicit switches may be trivial for experts but are confusing for students.

Students confuse levels [5]; they often explain phenomena on only one level [6] or do not interrelate concepts on different levels of organisation [7], which can also be called a lack of vertical coherence according to Verhoeff [8]. Besides, students' "misconceptions at one level can affect ( ... ) (their) understanding at other levels [9] (p. 310). These examples show that some of the students' everyday conceptions can be traced back to difficulties in dealing with levels of organisation. Insights into 
learning difficulties related to levels of organisation can be gained from publications on various biological topics (Table 1).

Table 1. Publications that offer insights into learning difficulties related to levels of organisation (according to [6], amended).

\begin{tabular}{cc}
\hline Biological Topic & Publications \\
\hline cell biology & {$[9-16]$} \\
genetics & {$[17-21]$} \\
physiology & {$[7,22-27]$} \\
ecology & {$[7,28,29]$} \\
evolution & {$[30-32]$} \\
\hline
\end{tabular}

Based on known learning difficulties in genetics, Knippels [19] suggests the Yo-Yo learning and teaching strategy. It incorporates the idea to make the levels of organisation explicit and to think to and from the levels over the course of several lessons. Other authors have since proposed learning strategies that focus on interrelating biological concepts using levels of organisation $[6,33,34]$. One key feature of such strategies is making the levels of organisation and their relationships explicit [6]. The aim of these strategies should be to foster horizontal and vertical coherence $[6,8]$.

"Yet, in spite of the ubiquity of the notion, levels of organization have received little explicit attention in biology or its philosophy" [35]. Therefore, teachers and science educators who intend to incorporate these strategies into their learning environment are facing two problems: articles of science education rarely describe the relationships between levels of organisation, and there is no consensus on the quality and quantity of the levels of organisation.

Because the term levels of organisation is used, in both science education and biology with diverse meanings, this article intends to present the state of the current discussion in both fields as the first step towards common ground in terms of levels of organisation.

\section{Research Questions}

Based on the goal to find adequate levels for teaching, we examined:

1. How do the authors describe the levels of organisation?

2. Which levels of organisation do the authors name?

3. How do the authors describe the relationship between different levels of organisation?

4. How do the authors describe the challenges of these levels for biological education?

5. How do the authors describe the benefit of these levels for biological education?

To answer these research questions (RQ), we analysed papers retrieved in a systematic literature review.

\section{Material}

A crucial step of a literature review is the search for relevant material. The process leading to the identification of material worth analysing followed a method presented by Rönnebeck et al. [36]. Ideally, a review includes every article that offers insights into the research questions under review. Therefore, to increase the chances of including relevant material, it is advisable to use very broad search terms. This strategy comes at a cost: the majority of the first output has to be excluded later on. To keep the number of the initial publications manageable, the decision has been made to use specialised databases. By using the internal filters of the databases, non-peer reviewed articles have been excluded in the first selection process.

Since the concept of levels of organisation is being discussed among both science educators and biologists from various fields, it has been decided to analyse papers of science education and papers published in biological journals. In order to minimise false-positive search results, we used three 
scientific databases that are specialised in the fields under review: ERIC (for English articles on science education), BIOSIS (for English biological articles) and Fachportal Pädagogik (for German articles on science education).

Due to levels of organisation being discussed in various fields, we used a set of keywords related to levels of organisation: biology, levels, biological, organisation/organization, hierarchy. Depending on the database, these queries had to be altered or translated.

For the second selection, we read the titles and abstracts of all articles included in the first selection and checked for relevance for RQ 1-5. Some articles were still included for a full-text reading because the relevance for RQ 1-5 could not be judged based on the abstracts. Articles with no statements on levels of organisation have been excluded. Additionally, the reference lists of the selected articles have been searched for sources not included in the corpus. Since only four articles have been added through cross-references, the scope of the initial search seemed to be appropriate.

In summary, articles have been selected for an in-depth analysis based on the following criteria (Figure 1):

1. Language: English or German (due to linguistic proficiency)

2. Type: articles in peer-reviewed journals

3. Date restrictions: none

4. Relevance: addresses levels of organisation

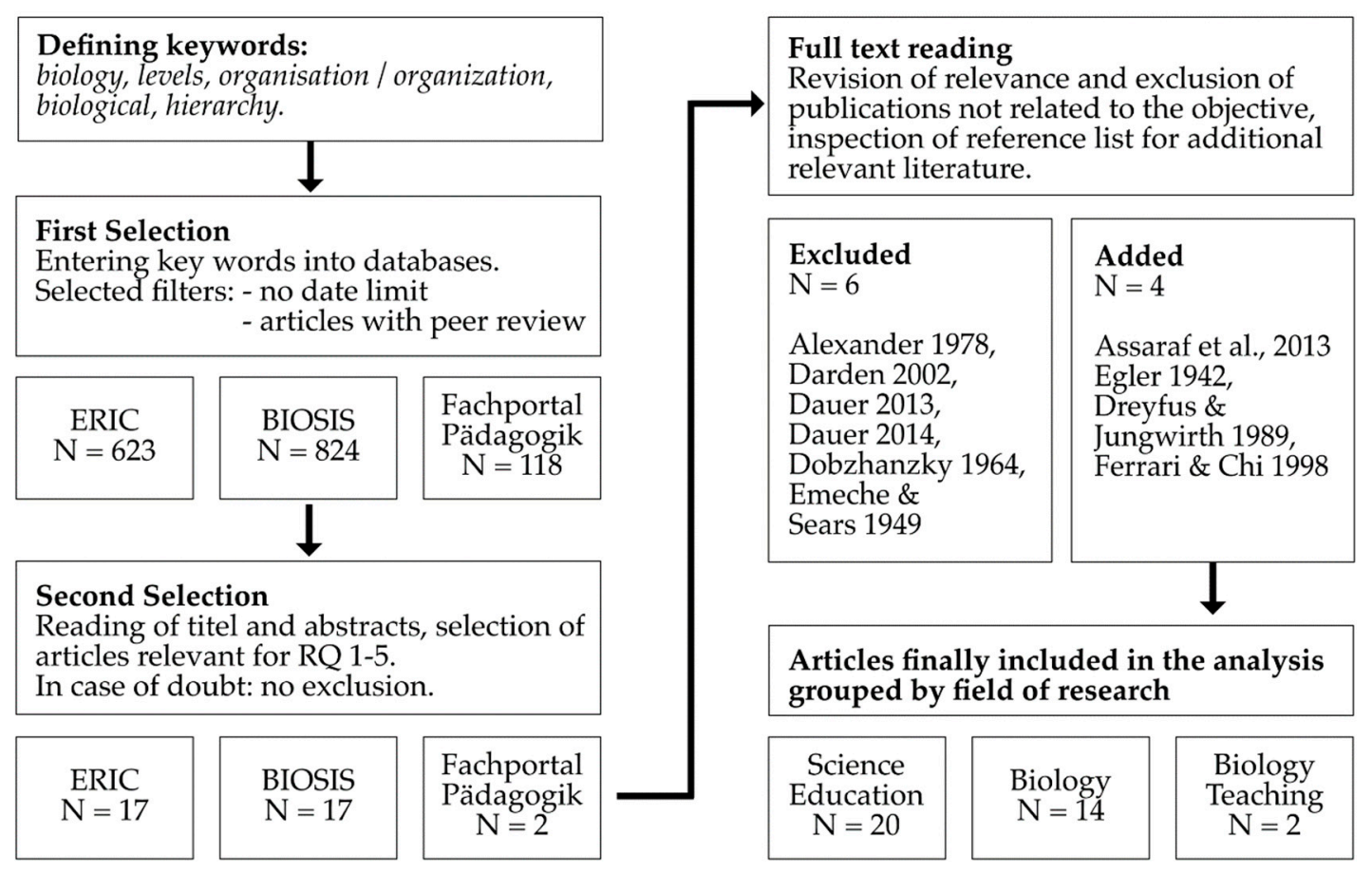

Figure 1. Schematic representation of the literature search and selection process.

The systematic literature research yielded a total of 36 articles. An overview of the selected articles is given in Table 2. 
Table 2. Selected publications on levels of organisation grouped by field of research.

\begin{tabular}{|c|c|c|c|c|}
\hline \multicolumn{2}{|c|}{ Field of Research } & \multirow{2}{*}{$\begin{array}{c}\text { Journals } \\
\text { American Scientist }\end{array}$} & \multicolumn{2}{|l|}{ Selected Publications } \\
\hline \multirow{13}{*}{\multicolumn{2}{|c|}{ Biology }} & & (Grene 1987) & [37] \\
\hline & & Biology \& Philosophy & (Craver \& Bechtel 2006) & [38] \\
\hline & & BioScience & (MacMahon Phillips, Robinson, \& Schimpf 1978) & [39] \\
\hline & & Comptes Rendus Biologies & (Auger \& Lett 2003) & [40] \\
\hline & & Ecology & (Rowe 1961) & [41] \\
\hline & & Frontiers in Physiology & (Findlay \& Thagard 2012) & [42] \\
\hline & & Interface Focus & (Okasha 2012) & [43] \\
\hline & & Journal of Vegetation Science & (Allen \& Hoekstra 1990) & [44] \\
\hline & & Philosophy of Science & (Egler 1942) & [45] \\
\hline & & Science & (Novikoff 1945; Wright 1959) & {$[46,47]$} \\
\hline & & $\begin{array}{c}\text { Studies in History and Philosophy of Biological } \\
\text { and Biomedical Sciences }\end{array}$ & (Brooks \& Eronen 2018) & {$[48]$} \\
\hline & & Synthesis & (Wimsatt 2006) & [49] \\
\hline & & The British Journal for the Philosophy of Science & (Feibleman 1954) & [50] \\
\hline \multirow{11}{*}{ Education } & \multirow{10}{*}{ Science Education } & Advances in Physiology Education & (Lira \& Gardner 2017) & [26] \\
\hline & & Education Sciences & (Knippels \& Waarlo 2018) & [51] \\
\hline & & International Journal of Science Education & $\begin{array}{l}\text { (Ferrari \& Chi 1998; Flores et al. 2003; Jördens et al. } \\
\text { 2016; Southard et al. 2017; Tripto et al. 2016) }\end{array}$ & {$[2,6,10,12,30]$} \\
\hline & & Journal of Biological Education & $\begin{array}{l}\text { (Dreyfus \& Jungwirth 1989; Düsing et al. 2018; } \\
\text { Knippels et al. 2005; Marbach-Ad \& Stavy 2010) }\end{array}$ & {$[9,18,20,29]$} \\
\hline & & Journal of Research in Science Teaching & $\begin{array}{c}\text { (Brown \& Schwartz 2009; Duncan \& Reiser 2007; } \\
\text { Songer \& Mintzes 1994) }\end{array}$ & {$[7,21,23]$} \\
\hline & & Journal of Science Education & (Ferrari \& Chi 1998) & [30] \\
\hline & & Journal of Science Education and Technology & (Wilensky \& Resnick 1999) & [5] \\
\hline & & Journal of the Learning Sciences & (Hmelo-Silver et al. 2007) & {$[52]$} \\
\hline & & Science Education & (van Mil et al. 2016; Williams, Montgomery et al. 2012) & {$[14,17]$} \\
\hline & & Research in Science Education & (Assaraf et al. 2013) & [27] \\
\hline & Biology Teaching & Unterricht Biologie & (Ruppert 2018; Sommer \& Harms 2010) & {$[53,54]$} \\
\hline
\end{tabular}




\section{Methods}

To ensure a systematic and orderly procedure, the analysis has been structured by means of a qualitative content analysis (QCA) [55]. By applying the rules of the QCA, the process of analysing the material has been built systematically. The results of the content analysis have been discussed in the workgroup to ensure a discursive validation.

For RQ 2 (Which levels of organisation do authors name?), we developed a first system of deductive categories: biosphere, ecosystems, populations, organisms, organs, tissues, cells. The analysis revealed the following additional categories: earth, species, organ systems, biochemical, molecules, proteins, chromosomes, genes, atoms.

For RQ 1, 3-5, categories had to be derived based on the analysis (inductive categories). According to the QCA, the texts have been searched for statements related to the research questions. Afterwards, these statements have been coded with inductive categories.

Our approach is best explained with an example. For RQ 1, we focused on descriptions of the levels of organisation. Therefore, we selected statements that described properties of levels, like: "The relationship between the components at these varied biophysical levels is frequently not straightforward due to properties that emerge only at the level of the system" [12] (p. 2). These statements would then be coded; in this case, one code would be Emergent Properties. Similar codes were merged into one.

The findings will be presented in the next section.

\section{Findings}

This literature review intends to provide insight into the range of descriptions of levels of organisation. Based on the research questions, the results of the analysis are being presented in four sections.

\subsection{Research Question 1: How Do the Authors Describe the Levels?}

The analysed articles lack general descriptions of levels. Authors describe levels as being ordered by complexity. Higher levels have a higher complexity than lower levels: "The concept of integrative levels of organization is a general description of the evolution of matter through successive and higher orders of complexity and integration" [46] (p. 209).

Additionally, the emergent nature of levels is being described, i.e., the circumstance that new properties appear on each level: "If we now zoom back out from the molecular level [ ... ], we can see that novel properties emerge at each step, properties that are not present at the preceding level" [56] (p. 3).

These new properties are formed through the interplay of system parts: "Each level of organization possesses unique properties of structure and behaviour which, though dependent on the properties of the constituent elements, appear only when these elements are combined in the new system" [46] (p. 209).

If some properties exist due to the interplay of lower levels, then examinations of such properties need to examine lower levels.

\subsection{Research Question 2: Which Levels of Organisation do the Authors Name?}

To answer this question, every article that explicitly names individual levels was analysed. Terminological variations such as ecosystems and ecologic systems have been unified. Levels that are named but explicitly rejected by the author were not counted. One example for an explicit rejection is this excerpt of Rowe [41] (p. 422): “'Deme,' 'population,' 'species,' 'flora'-all highly abstract taxonomic categories-must likewise be rejected as first-order objects of study."

Authors name varying sets of up to 21 different levels, ranging from subatomic particles to the universe. The following paragraphs will offer insights into the levels that authors of the fields of 
Biology and Science Education name. A detailed overview of the levels that each article names is given in Tables A1-A3 (Appendix A).

\subsubsection{Biology $(\mathrm{N}=14)$}

In their papers, authors name the following levels (ordered by scale): subatomic particles, atoms, molecules, organelles, cells, tissues, organs, organ systems, colonies, demes, populations, communities, taxonomic categories (species, genus, family, order, class, phylum, kingdom), ecosystems, landscapes, biomes, biosphere, and universe.

The most frequently named levels are: organisms, cells, ecosystems, organs, populations. The least frequent levels are: earth, colonies, universe, atoms, subatomic particles (Figure 2).

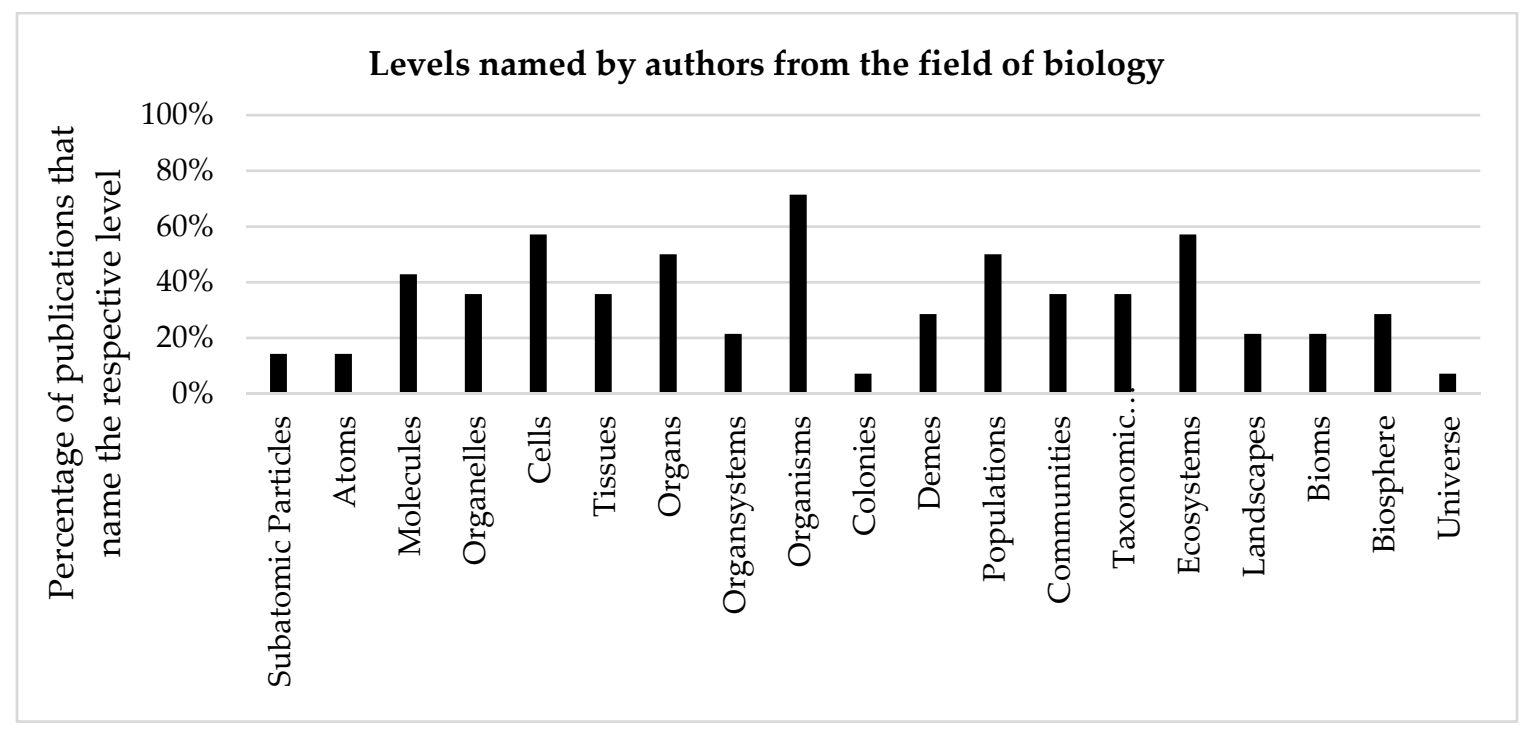

Figure 2. Coding results for individual levels of organisation explicitly named in articles from the field of biology $(\mathrm{N}=14)$. The percentage refers to the number of papers that name the respective level at least once.

\subsubsection{Education $(\mathrm{N}=22)$}

Since both articles on science education and biology teaching focus on levels in an educational context, we have combined them into one group. Articles on science education and biology teaching name the levels of atoms, molecules, organelles, cells, tissues, organs, organ systems, organisms, populations, communities, taxonomic categories (species), ecosystems, biosphere, and earth.

The most frequent levels are: organisms, cells, molecules, organs and populations. The least frequent levels are: atoms, taxonomic categories (species), biosphere, organ systems and earth. None of the analysed papers name the levels of subatomic particles, colonies, demes, landscapes, biomes, and universe (Figure 3). 


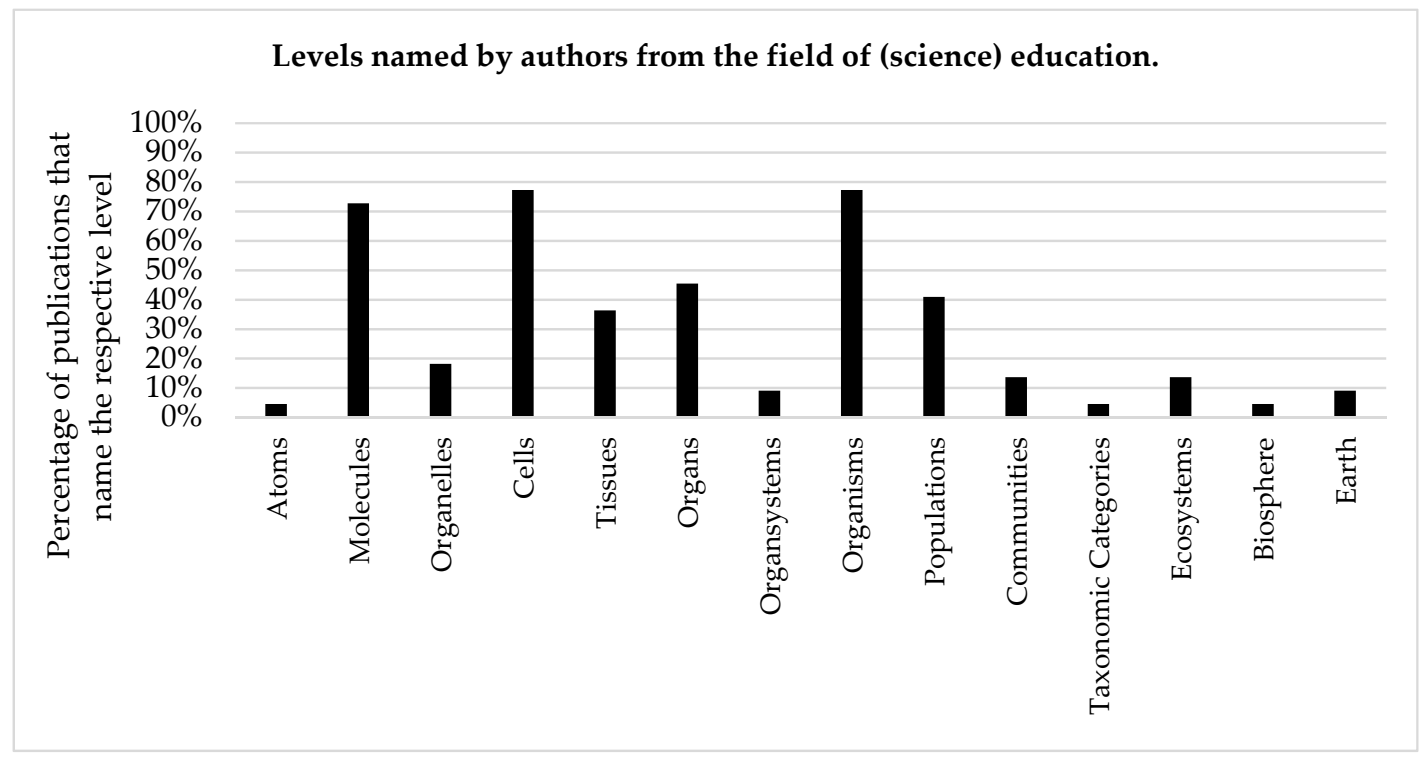

Figure 3. Coding results for individual levels of organisation explicitly named in articles from the field of education $(\mathrm{N}=22)$. The percentage refers to the number of papers that name the respective level at least once.

\subsubsection{Summary}

Taking all articles from the fields of biology and education together, the most frequent levels are (starting with the most frequent): organisms, cells, molecules, organs, and populations. The least frequent levels are: universe, colonies, earth, subatomic particles, and atoms (Figure 4).

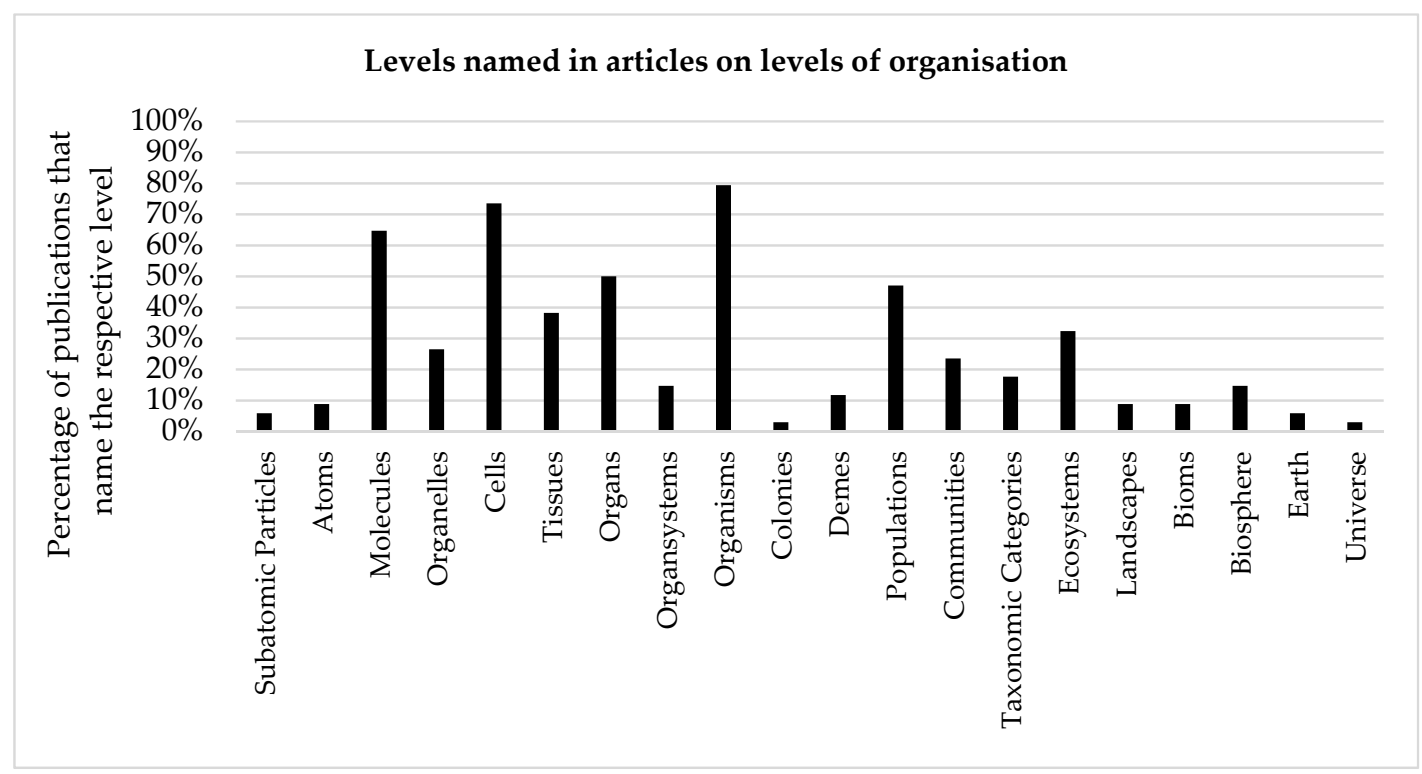

Figure 4. Coding results for individual levels of organisation explicitly named in the analysed articles $(\mathrm{N}=36)$. The percentage refers to the number of papers that name the respective level at least once.

\subsubsection{Range of Levels}

The number of levels that authors name varies. The article with the most levels names 21 , the one with the least levels focusses on just two. For the field of biology, the mean is 9.4 levels. Science educators name a mean of just 4.4 levels, with a range of two to eight levels. The lower mean might be due to the fact that the articles of science educators are aimed at specific biological topics or phenomenon, whereas the biological articles focus on the concept of levels in general. 


\subsubsection{Science Education Articles Use Different Levels Based on the Underlying Phenomenon.}

Articles on Science Education discuss levels of organisation in the context of different biological phenomena. Therefore, we were able to group articles with similar phenomena. This resulted in a set of five central fields of biology: physiology, ecology, evolution, genetics and cell biology. Articles of each group were then analysed with regard to the levels they explicitly name (see Appendix A Table A2 for further information).

The articles on physiology $(\mathrm{N}=4)$ use levels ranging from molecules to the communities, with a focus on cells, organisms, and molecules. Levels from atoms to the earth are featured in articles on ecology $(\mathrm{N}=3)$, but with a focus on organisms and molecules. While articles on evolution $(\mathrm{N}=2)$ mention only the levels of molecules, organisms, and populations, all of them are mentioned equally often. In the context of genetic phenomena $(\mathrm{N}=4)$, levels from molecules to populations are being used. The levels of molecules and cells are named most frequently. In articles with phenomena of cell biology $(\mathrm{N}=5)$ levels from molecules to populations are being named as well. In contrast to genetics, the levels of organisms and cells are named most frequently (Figure 5).

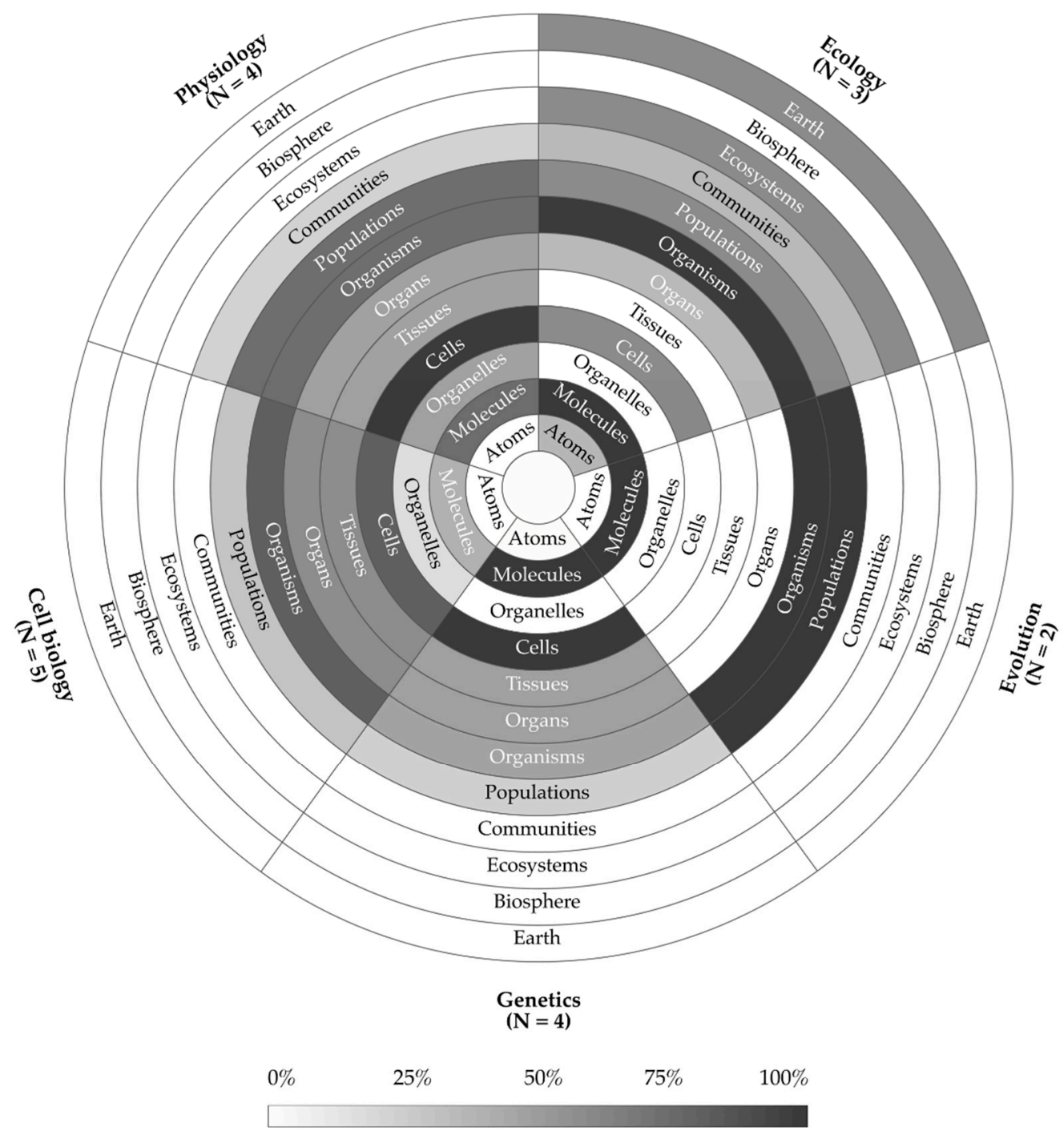

Figure 5. Coding results for levels named in science education articles on five central fields of biology. Colour density represents the frequency of articles naming the respective level. Articles which refer to similar phenomena name similar levels; articles which refer to different phenomena name different levels of organisation. 


\subsection{Research Question 3: How Do the Authors Describe the Relationships between Levels?}

In order to answer this question, we analysed how authors describe the relationship between all or individual levels.

\subsubsection{Dependence of Levels}

Authors described either a one-sided dependence or an interdependence of the levels. Feibleman [50], for example, describes a one-sided dependence when he states: "In any organization, the higher level depends upon the lower" [50] (p. 63). Whereas, MacMahon [39] describes the relationship as interdependent: "a given level may coact with other levels above or below it in the series. All such coactions determine function. [ ... ]" [39] (p. 701). The interdependence becomes apparent when parts of a system are being removed. "Just as cells do not exist in isolation in the organism, neither do organs or organ-systems [ ... ]" [46] (p. 211).

In addition to levels being dependent from one another, authors describe five different types of relationships or dependences between all or specific levels of organization:

1. The part-whole relationship,

2. The flow-of-information relationship,

3. The matter-energy relationship,

4. The coevolutionary relationship, and

5. The phylogenetic relationship.

\subsubsection{The Part-Whole Relationship}

Characterising for the part-whole relationship is the idea that one can view objects both as a whole or part of a bigger whole, as described by Rowe [41]: "Each object will then constitute the immediate environment of the object at the level below while forming a structural-functional part of the object at the level above" [41] (p. 421).

The duality of parts and wholes is described by Novikoff [46] as: "What were wholes on one level become parts on a higher one" [46] (p. 209) (Figure 6).

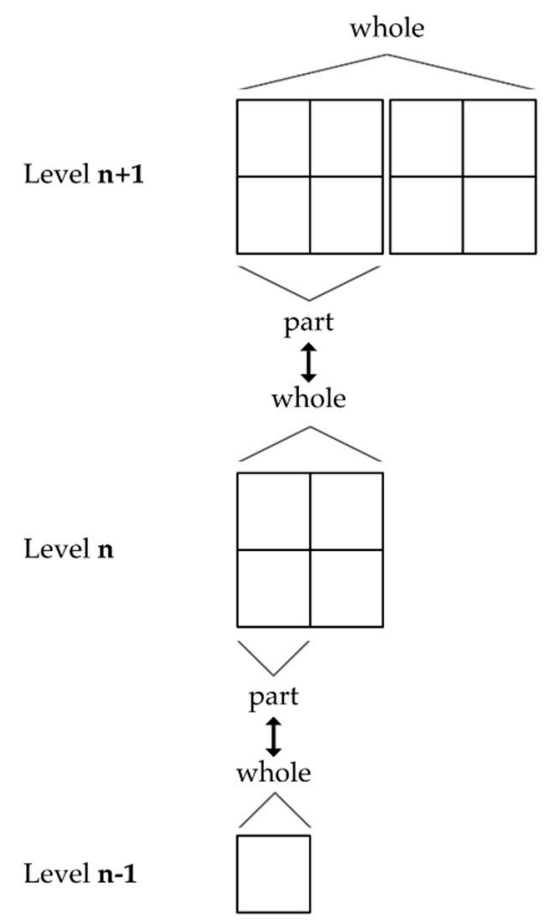

Figure 6. Duality of parts and wholes with respect to levels of organisation. 
Whether a structure should be considered part or whole is up to the observer, since " $[\ldots]$ the question of which is parts and which is whole becomes merely a question of the level chosen for analysis, for there is some level at which every organisation is a part of some whole and another level at which it is a whole to its parts" [50] (p. 63).

\subsubsection{The Flow-of-Information Relationship}

"This kind of hierarchy, in which information flows between levels in both directions, as well as between units within a given level, we may call a hierarchy of control". [37] (p. 508)

"And again, it is the flow of information both horizontally and vertically that makes the organism an integrated, working whole". [37] (p. 508)

System parts of living organisms are interrelated through both the part-whole relationship and the flow-of-information relationship. We may call the interplay of these two relationships the physiological relationship in accordance with [39].

\subsubsection{The Matter-Energy Relationship}

The matter-energy relationship is described as follows. Since " $[\ldots]$ an ecosystem is a set of organisms and inanimate entities connected by exchanges of matter or energy" [39] (p. 701), organisms in an ecosystem are interrelated through the exchange of matter and energy. Both matter and energy and the exchanging entities are part of the ecosystem.

\subsubsection{The Coevolutionary Relationship}

MacMahon et al. [39] describe coevolutionary relationships as interactions, "that affect each other's expected reproductive success" [39] (p. 701). The effect of such interactions can be positive, negative or neutral.

"The combinations of positive, negative, and neutral effects on expected reproductive success are embodied in the familiar concepts of competition, mutualism, commensalism, etc. (Burkholder 1952). These are specific kinds of coevolutionary interactions". [39] (p. 701)

Coevolutionary relationships can occur between different coevolutionary units. The coevolutionary units are "organisms and multiorganism aggregations known as demes, populations, and communities" [39] (p. 702).

In order to affect each other's reproductive success, organisms not only have to exist in spatial, but in temporal proximity as well. Coevolutionary relationships only occur between organisms living at the same time. Yet, there are other relationships that occur between organisms that do not coexist in the same period of time: phylogenetic relationships.

\subsubsection{The Phylogenetic Relationship}

Every organism is connected to others through a continuum of relatedness, in other words, through common ancestors. "This continuum of relatedness is arbitrarily partitioned by a hierarchy of terms (Figure 1). In the ideal case, the terminology will reflect levels of phylogenetic relationship. The problems in the phylogenetic line are generally those of choosing appropriate characters to establish levels. The characters should reflect [the] degree of difference. Certainly, there is no current consistency in [the] application of terms. (Are two passeriform bird families as distinct from each other as two araneomorph spider families?)" [39] (p. 702).

\subsection{Research Question 4: How Do the Authors Describe the Challenges of Levels for Biological Education?}

What are possible challenges researchers and educators have to be aware of, when using levels of organisation for teaching? Only three of the articles analysed in this review mention such challenges. 
Knippels and Waarlo [51] reviewed cases of the Yo-Yo teaching and learning strategy (Yo-Yo-thinking). In their study, they reviewed the articles regarding difficulties concerning the implementation of YoYo-thinking. Knippels and Waarlo [51] found few descriptions of challenges. Only one of the articles Knippels and Waarlo [51] reviewed offers insights into challenges: Van Mil et al. [14] reported that their teaching approach was difficult for teachers.

However, what is challenging for students? Knippels and Waarlo [51] suggest that students might confuse concepts of systems-theory and empirical part-whole entities. Accordingly, Assaraf, Dodick and Tripto [27] point out that students focus on system components rather than their interactions.

The small number of challenges mentioned is countered by a multitude of benefits, which will be presented in the next section.

\subsection{Research Question 5: How Do the Authors Describe the Benefit of Levels for Biological Education?}

Biological phenomena need to be examined on multiple levels. "Knowledge of the laws of the lower level is necessary for a full understanding of the higher level; yet the unique properties of phenomena at the higher level cannot be predicted, a priori, from the laws of the lower level" [46] (p. 219). Since higher levels too need to be examined, at least three levels need to be dealt with, "a focal level, a lower level, and a higher one" [37] (p. 512). Therefore, one should "utilize resources at various levels, spanning these to determine appropriate loci for objects, processes, and phenomena, and explicate their relations." [49] (p. 17).

Levels can structure scientific problems and guide investigations. Since system parts are interrelated, parts cannot be examined isolated from the system [46]. "Conventional levels of organization are not scale-dependent, but are criteria for telling foreground from background, or the object from its context" [44] (p. 7). Or, as Brooks \& Eronen [48] (p. 1) put it, it is the levels' "use as a descriptive term that captures the relevant details of interest in a system."

Levels not only help to focus on what is relevant with respect to a research question, but they may also help to find answers because the analysis of mechanisms and functions requires different levels. "To analyse a mechanism, we drop down one level. This is obvious when we consider that analysis moves from the whole to its parts. For we should not expect the parts to be on the same level of analysis as the whole of which they are the parts" [50] (p. 61).

According to van Mil et al. [14] (p. 524), in order to answer the question "How does it arise from the underlying parts and their activities?" one has to analyse lower levels.

Yet, "to find the purpose of any organisation we would move up one level, for then we are considering the organisation as itself a part of some higher and more complex organisation. We could perhaps study the kidney and its functions without constituent tissues and without reference to the somatic organism in which it plays a certain role or roles, but we would not get very far without the introduction into our considerations of both adjacent levels" [50] (p. 61). Therefore, if the question is: "What is its role or function, or how does it contribute to a larger whole? [14] (p. 524) one has to move up one level.

\section{Discussion}

\subsection{Summary}

Based on common learning difficulties in biology authors like Knippels [19] and Jördens et al. [6] they argue that levels of organisation and their relationships should be used in instruction and made explicit. Yet, teachers and science educators who intend to incorporate these strategies into their learning environment are facing two problems: articles of science education rarely describe the relationships between levels of organisation, and there is no consensus on the quality and quantity of the levels of organisation. In order to give teachers and researchers an overview of the current state of discussion, we summarize: 
RQ 1: General descriptions of the levels of organisation were scarce. Authors focussed on the order of levels and emergent properties.

RQ 2: Based on the analysis of $N=36$ articles, it can be stated that there is currently no consensus on which levels of organisation form a consistent system. Authors name different sets of up to 21 different levels ranging from subatomic particles to the universe. Of the 36 articles reviewed, the most commonly used levels are organisms $(79 \%)$, cells $(74 \%)$, molecules $(65 \%)$, organs $(50 \%)$, and populations $(47 \%)$. Additionally, we were able to show that articles on Science Education use specific levels of organisation based on the phenomenon they focus on (Figure 6).

RQ 3: In addition to levels being depended on other levels, we found descriptions of four different relationships between levels of organisation:

1. The physiological relationship (part-whole relationship and the flow-of-information relationship);

2. The matter-energy relationship;

3. The coevolutionary relationship; and

4. The phylogenetic relationship.

RQ 4: In the articles we analysed, authors rarely discuss challenges of levels of organisation. One challenge we were able to identify was pointed out by Assaraf, Dodick and Tripto [27]: students focus on system components rather than their interactions. Knippels and Waarlo [51] added that students might confuse concepts of systems-theory and empirical part-whole entities.

RQ 5: Levels can structure scientific problems and guide investigations. According to the analysed articles, this is the main benefit of the levels. Levels guide investigations mainly by focussing on what is essential in relation to the research question. Mechanisms are to be examined in lower levels, functions in higher levels.

By looking at the results from a bird's eye view, we will now highlight and discuss the results.

- $\quad$ For RQ 1, we reflect on the nature of levels of organisation.

- For RQ 2, we discuss differences in names for specific levels, the usage of different levels based on the phenomenon and differences in the order of levels.

- For RQ 3, we address whether levels are interdependent or only lower levels depend on higher levels. Additionally, we focus on qualitative differences of relationships between levels.

- For RQ 4 and 5, we elucidate the challenges and benefits of levels of organisation.

\subsection{The Nature of Levels of Organisation}

"Yet, in spite of the ubiquity of the notion, levels of organization have received little explicit attention in biology or its philosophy. Usually they appear in the background as an implicit conceptual framework that is associated with vague intuitions. Attempts at providing general and broadly applicable definitions of levels of organization have not met wide acceptance" [35]

Based on our review, we can confirm this statement of Brooks and Eronen. Articles answered the questions of how levels are ordered, how they behave and relate to each other, yet did not explicitly describe, what levels are.

Since the goal in education is an explicit reflection of the levels [6], teachers at some point will have to address the nature of levels. We propose to introduce levels of organisation themselves as zoom levels. Zooming is a concept that students are very familiar with. Zooming-in focusses on details; zooming-out includes the context. Zooming relates to the idea that levels are "criteria for telling foreground from background" [44] (p. 7). Similar to the Yo-Yo teaching and learning strategy [20], zooming in and out should be guiding for learning environments.

Now, with a working definition of what levels of organisation are, we may discuss which levels or organisation there are. 


\subsection{Ordering Levels}

Looking at the results of RQ 2, it is apparent that some authors $[43,47,57]$ use the level of genes instead of the level of molecules. Yet, explaining or understanding the causal chain from genes to traits of organisms requires the use of not only genes but other molecules like proteins as well [14]. Therefore, the more general level of molecules should be used instead of the level of genes, since the argument includes both genes and proteins.

Above the said level of molecules, Auger \& Lett [40] name a biochemical level. Since chemical reactions happen between molecules and atoms, for most phenomena, a distinct biochemical level offers no benefit as opposed to the level of molecules and level of atoms. Furthermore, the biochemical level focuses mainly on the (biochemical) processes, whereas the levels of molecules and atoms focus on both structures and processes. Therefore, the levels of molecules and atoms may be more relevant for an educational use.

In the last paragraph of Section 5.1., we were able to show that articles in the field of science education often use different levels based on the phenomena the articles are focusing on. Authors like MacMahon et al. [39] and Novikoff [46] draw attention to this selective use: Depending on the phenomenon, levels "[ ... ] might be skipped; e.g., for unicellular organisms, tissue-level relationships are not meaningful nor is the deme concept appropriate for an asexual form" [39] (p. 700). According to MacMahon et al. [39] (p. 700), the opposite may also be necessary since their "categories are not exhaustive, but merely the most commonly used; others, such as sub-family or organelle, can be used." Novikoff [46] (p. 209) calls such sub-levels "mesoforms" and argues that the categories have soft borders since "no boundary in nature is fixed and no category air-tight." Hence, the levels required for explanations depend on the phenomenon under examination.

Another inconsistency is the placement of taxonomic categories such as species between the level of ecosystems and communities or populations as in [37,43,47]. Taxonomic categories are useful for explanations of evolutionary processes, but they do not fit in a linear systematisation of levels beneath ecosystems, because no taxonomic group is part of the ecosystem, only individual organisms are. This will be further discussed in the following sections.

\subsection{Levels of Organisation Can Be Related through Different Relationships}

In Section 5.3. We analysed how authors describe the relationships between levels of organisation. Feibleman [50] described lower levels being dependent on higher levels. Such a one-sided dependence is incomplete because lower levels are as depended on higher levels as higher levels are on lower levels. Cells, for instance, are depended on organs, such as lungs, blood, and vessels for oxygen. Levels should therefore be described as interdependent. In order to grasp the inherent inconsistency of the previously described order, a closer inspection of the different relationships is needed.

The physiological relationship, which relates to the level of organisms and the levels below the organism, does not fit the whole range of levels. The parts of an organism are in physical contact and therefore are perfect parts and wholes. Others, such as populations, are not in physical contact, but they are related. Rowe [41] draws on this discussion when he argues that leaf (organ) to plant (organism) is a different relation than plant (organism) to community. Hence, the relationship between organisms, populations, and community is a coevolutionary relationship [39].

The coevolutionary relationship does not just connect the level of populations and organisms as described by MacMahon et al. [39], but the levels below the organisms as well. A salient example is the symbiogenesis, i.e., the genesis of eukaryotic from prokaryotic cells. The levels or units of coevolution are what others, e.g., Dawkins [58], call units of selection. The principle of natural selection (PNS) can affect even the levels of molecules. From the level of molecules, the PNS can be extended to all subsequent levels like organelles, cells, tissues, organs, organisms, and populations [59]. For this reason, the coevolutionary relationship should connect all levels between molecules and populations.

For ecosystems, the matter-energy relationships between the organisms of the ecosystem are characteristic. Therefore, matter-energy relationships relate organisms, ecosystems, biosphere, and the 
earth. Yet, the matter-energy relationship not only interrelates the levels earth, biosphere, ecosystem and organism, but the levels below the organism as well. Parts of a living organism continuously exchange matter and energy, e.g., oxygen. This will be displayed in Figure 7.

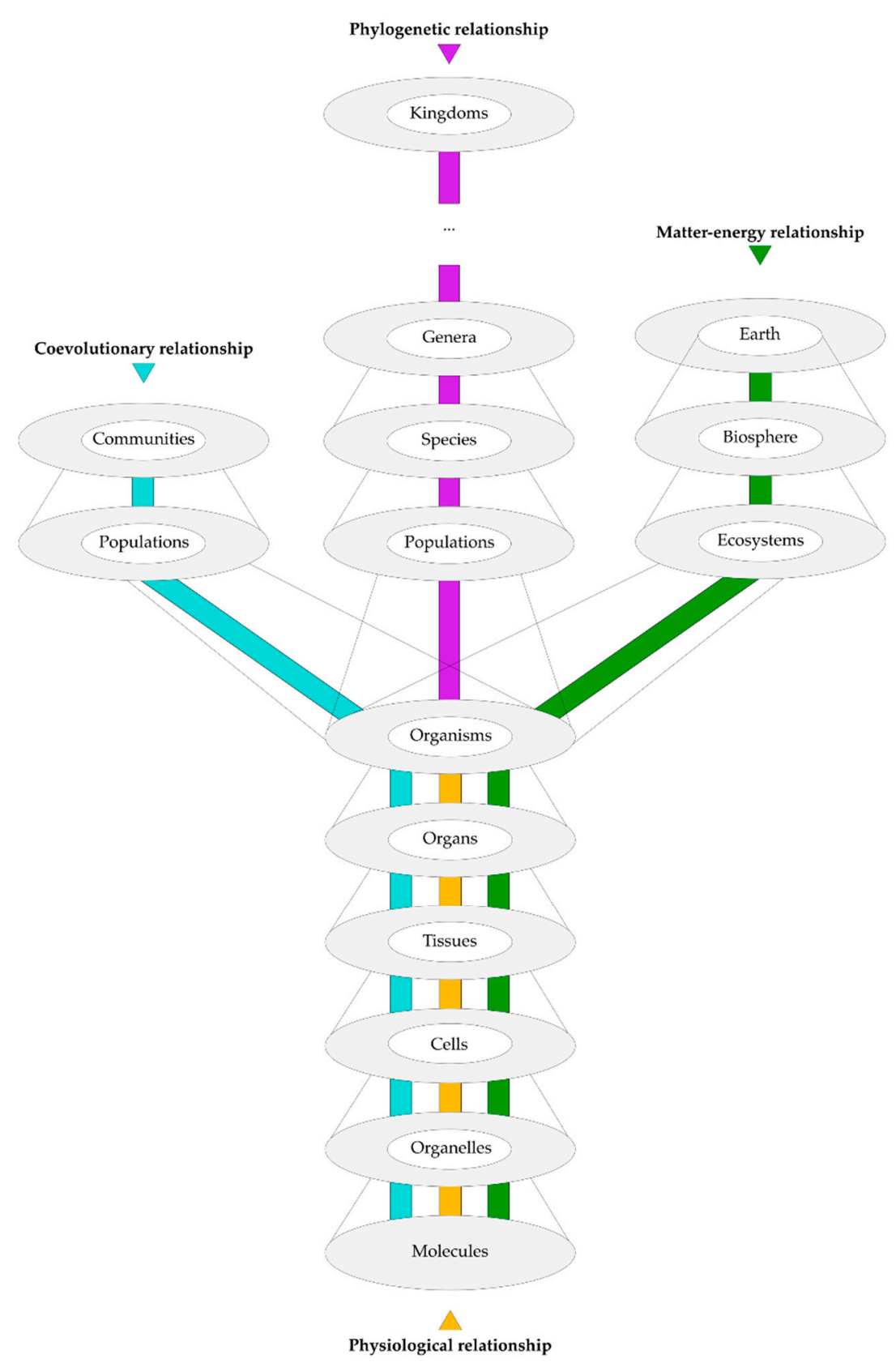

Figure 7. System of levels of organisation ordered by relationships for educational purposes based on [39]. The system makes the relationships between the levels explicit and incorporates the idea of zooming in. By distinguishing between the relationships, it is made clear which levels are apt for which phenomena.

By looking back in time and focusing on relatives of decreasing relatedness, one explores the whole of the kinship of organisms. Organisms are related to their kinship through phylogenetic relationships.

By focusing on the different relationships, it becomes apparent why communities and populations, as well as species, do not fit between organism and ecosystems. Neither communities nor species are exchanging matter and energy in an ecosystem. Only their parts, the organisms do. 


\subsection{Levels of Organisation Can Be Formed, Based on Relationships}

Coevolutionary relationships, matter-energy relationships and phylogenetic relationship form different subsets with an increasing complexity of the same wholes (see Figure 7).

In a system, the relationships serve as ordering criteria for the formation of levels. The relationship is the criteria to decide which parts of the system fall into the new category, respectively, the new level.

Starting from the level of the organism, one could move up to the next, more complex level. If one focusses on coevolutionary relationships, that would be the level of the population. Part of the level of the population would be all organisms of the same species that live in the same area and therefore are in a close coevolutionary relationship. If one focusses on matter-energy relationships, it would be the level of the ecosystem. All organisms that exchange matter and energy, as well as the non-living system components, would be part of this level. Accordingly, if one focusses on phylogenetic relationships, the next level would be the level of the species. The level of the species includes all organisms that share a common ancestor.

Since the relationships determine the formation of new levels, their differences need to be examined more closely.

\subsection{Relationships between Levels of Organisation are Qualitatively Different}

There are some qualitative differences between the relationships The frequently named emergent properties of levels through the interaction of lower parts appear only within the (a) physiological relationship, the (b) matter-energy relationship and the (c) coevolutionary relationship. Examples: (a) The integration of structures and processes in cells cause new properties of tissues; (b) Through the matter-energy cycles between organisms in an ecosystem, a limited amount of matter is sufficient to support an ecosystem for a basically unlimited period of time; (c) Coevolutionary relationships, i.e., the interactions of organisms over time cause changes in populations.

At first glance, matter-energy relationships (b) and coevolutionary relationships (c) appear similar because (c) often entails (b). Coevolutionary relationships like mutualism, predator-prey or host-parasite can be described as matter-energy relationships as well but this is quite less or not the case for competition between or within populations and territorial behaviour. To pursue matter-energy relationships means being able to describe the circulation of matter and the flow of energy on different levels of organisation. In an ecosystem, for instance, living organisms are interconnected by exchanging carbon and its chemical compounds within the carbon cycle [19]. Coevolutionary relationships, by contrast, emerge through mutual interactions between entities on different levels of organisation, thereby affecting changes.

The levels connected via the phylogenetic relationship (see Figure 7) are just aggregations of more and more organisms with a declining degree of relationship. Since the criterion is not interaction, but phylogenetic relationship, it is not emergent in a sense that the parts form a new whole with new properties.

Another difference exists in the degree of the interdependence of the levels. There is a strong interrelation between the levels connected by the physiological relationship. Failure at any level can cause severe damage to the organism. A lesser degree of interdependence is the matter-energy relationship. The extinction of individual organisms may not destroy but change an ecosystem.

Organisms in phylogenetic relationships are not interdependent. Since living organisms would not exist without their ancestors, one may call it a one-sided dependence.

\subsection{Meeting the Challenges and Benefits}

Knippels and Waarlo [51] stated that students might confuse concepts of systems-theory and empirical part-whole entities and, therefore, have difficulties understanding emergent properties. Understanding a system as just a sum of its parts undercuts the importance of the interactions. 
Assaraf, Dodick, and Tripto [27] pointed out that students focus on system components rather than their interactions. Reflecting with students, which structures relate to which level might strengthen these misconceptions. Thus, the reflexion should include the relationships. Since the relationships are manifested through interaction between system components, an explicit reflexion might foster an understanding of systems as being formed by interacting and interrelated components.

Ideally, levels may structure the investigation of biological phenomena, by guiding students either upwards or downwards. Mechanisms are to be examined in lower levels, functions in higher levels.

\section{System for Educational Purposes}

Since levels above the organism cannot be stacked in a linear order, an alternative to the linear systematisation is needed. MacMahon et al. [39] propose a system that places both taxonomic groups and ecosystems side by side above organisms. It is based on the premise that the levels are related through different kinds of relationships. Based on research questions 1-3, and [39], we propose a system of levels for educational purposes (Figure 7).

The proposed system of levels of organisation is based on two premises: Zooming and relationships between levels. Since there are qualitative differences between the relationships, the system reflects these differences in its structure. The relationships can thus be made explicit. We propose that the relationships between the levels of organisation should be part of meta reflexion in instruction too, in order to foster vertical coherence [8].

This system also meets the needs of phenomenon specific levels. Depending on the phenomenon or, more precisely, the research question, different relationships and levels have to be used.

\section{Implications}

Based on the results of RQ 1 to 5, we present a system of levels (Figure 7). Depending on the phenomenon and the research question, different sets of levels and relationships are apt in school settings. In order to teach the carbon cycle, for example, it may be fruitful to focus on matter-energy relationships and to trace matter [29]. Making these different relationships explicit as in Figure 7 may help students construct causal connections between levels of organisation and therefore between biological phenomena and their causes. Furthermore, the system may help teachers and researchers choose the levels necessary for biological explanations.

Most notably, this is the first literature study to our knowledge on the use and implications of levels of organisations in both biology and science education. Our results may help teachers and science educators implementing levels of organisation into their learning environments and therefore to identify parts, processes, and their relationship to each other, which are all crucial aspects of systems thinking $[1,2]$.

Systems thinking is described as a cognitive skill [1] that is much needed, to understand interrelations and dependences in systems and demands students "to translate environmental problems, such as water pollution, into a more coherent understanding of the environment" [60] (p. 519). Understanding phenomena like water pollution or the carbon cycle as systems may be crucial to peaceful coexistence with the environment [61]. Students who can understand their environment as a system might be better equipped to evaluate its changes $[62,63]$.

In our project, we analysed how authors describe levels of organisation. Based on our categories, subsequent research could analyse, how authors think about levels of organisation.

We argue that the appropriateness of levels should be evaluated with respect to their ability to foster students' understanding. There is not yet valuable insight into the challenges of students with regard to working with levels of organisation (5.4.). Further research should consequently focus on the benefits and challenges of explicit reflection of said levels. Teaching experiments are currently being conducted, based on the developed systematisation, in order to evaluate students' learning gains and difficulties with interventions that feature levels of organisation. 


\section{Limitations}

Nevertheless, there are some limitations of this paper we would like to address. The first one concerns the databases and keywords used to gather the first selection of articles. By using relevant keywords and databases, we aimed at a comprehensive collection of material.

Although due to the complex process leading to the identification of relevant articles, we are confident about having sufficient material, there is still a possibility that we did not identify some relevant papers. Different keywords or databases might have led to additional publications.

Another decision we made was to limit the language of the material to English and German. Including other languages might have led to an even broader collection of material. To account for these limitations, we tried to make the selection process as transparent and explicit as possible.

Furthermore, the proposed system of levels has not yet been empirically tested. As of now, it is based solely on the current state of discussion about levels of organisation.

Author Contributions: Both authors listed have made a substantial, direct and intellectual contribution to the work, and approved it for publication.

Funding: This research received no external funding.

Acknowledgments: We thank our colleagues of the Institute for Science Education of Leibniz Universität Hannover. The publication of this article was funded by the Open Access fund of Leibniz Universität Hannover.

Conflicts of Interest: The authors declare no conflict of interest. 


\section{Appendix A}

Table A1. Biological articles and the levels they name. Some articles mention levels but explicitly reject certain levels. These rejected levels are being highlighted by crossing them out.

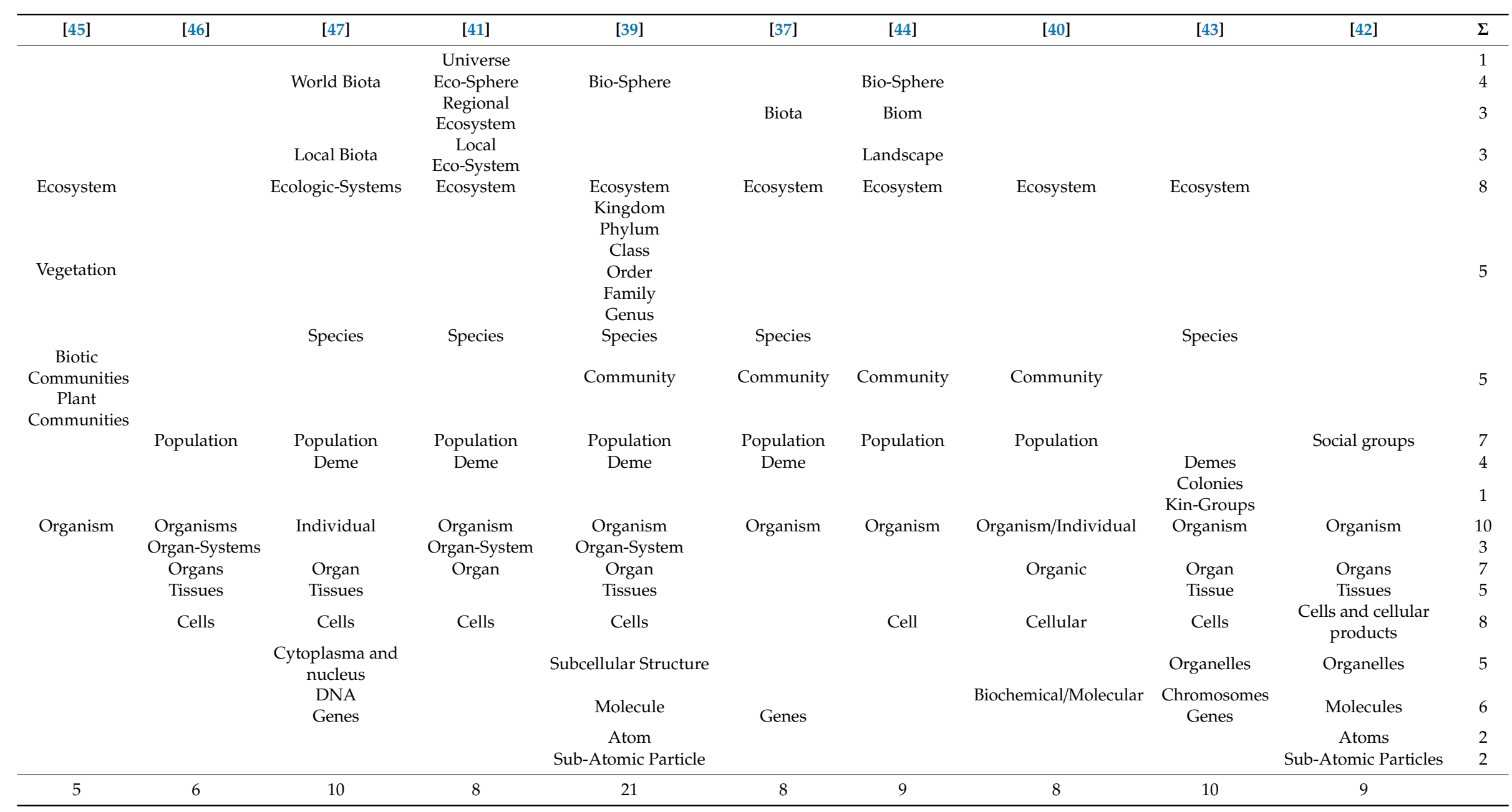


Table A2. Science education articles and the levels they name.

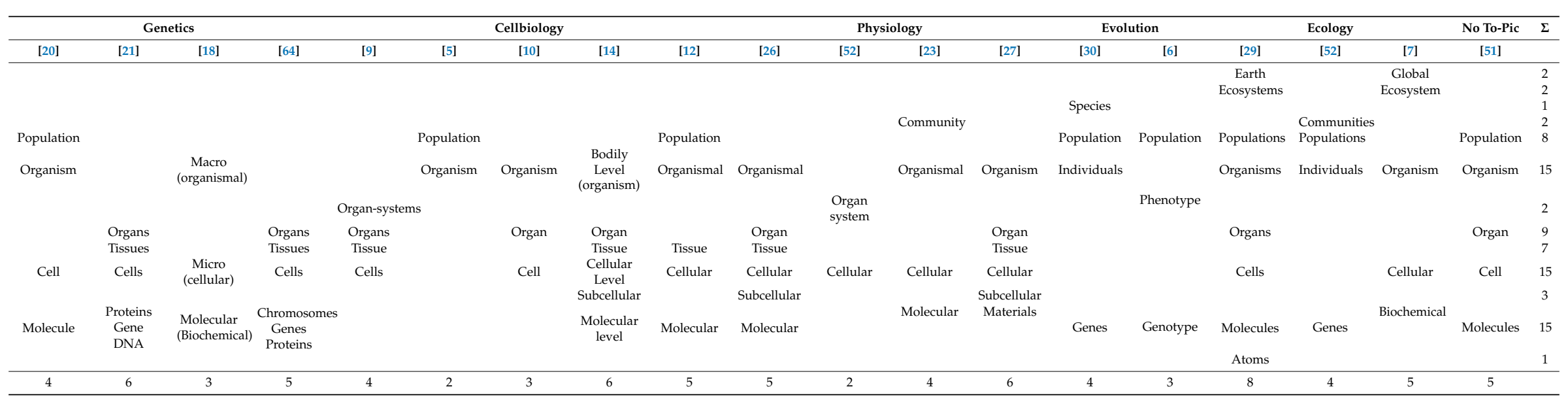


Table A3. German teaching articles and the levels they name.

\begin{tabular}{ccc}
\hline [53] & [54] & $\Sigma$ \\
\hline Biosphäre & & 1 \\
Ökosystem & & 1 \\
Biozönose & & 1 \\
Population & Organismisch & 2 \\
Organismus & & 1 \\
Organ & & 1 \\
Gewebe & Zellulär & 2 \\
Zelle & & 1 \\
Organelle & Molekular & 2 \\
(Makro-) Moleküle & 3 & \\
\hline 10 & &
\end{tabular}

\section{References}

1. Verhoeff, R.P.; Knippels, M.-C.P.J.; Gilissen, M.G.R.; Boersma, K.T. The Theoretical Nature of Systems Thinking. Perspectives on Systems Thinking in Biology Education. Front. Educ. 2018, 3. [CrossRef]

2. Tripto, J.; Ben-Zvi Assaraf, O.; Snapir, Z.; Amit, M. The 'What is a system' reflection interview as a knowledge integration activity for high school students' understanding of complex systems in human biology. Int. J. Sci. Educ. 2016, 38, 564-595. [CrossRef]

3. Robinson, W.S. Zooming in on Downward Causation. Biol. Philos. 2005, 20, 117-136. [CrossRef]

4. Kadereit, J.W.; Kost, B.; Körner, C.; Sonnewald, U. Strasburger Lehrbuch der Pflanzenwissenschaften, 37th ed.; Springer: Berlin/Heidelberg, Germany, 2014; pp. 1-931.

5. Wilensky, U.; Resnick, M. Thinking in Levels: A Dynamic Systems Approach to Making Sense of the World. J. Sci. Educ. Technol. 1999, 8, 3-19. [CrossRef]

6. Jördens, J.; Asshoff, R.; Kullmann, H.; Hammann, M. Providing vertical coherence in explanations and promoting reasoning across levels of biological organization when teaching evolution. Int. J. Sci. Educ. 2016, 38, 960-992. [CrossRef]

7. Brown, M.H.; Schwartz, R.S. Connecting photosynthesis and cellular respiration: Preservice teachers' conceptions. J. Res. Sci. Teach. 2009, 46, 791-812. [CrossRef]

8. Verhoeff, R.P. Towards Systems Thinking in Cell Biology Education; CD- $\beta$ Press: Utrecht, The Netherlands, 2003.

9. Dreyfus, A.; Jungwirth, E. The pupil and the living cell: A taxonomy of dysfunctional ideas about an abstract idea. J. Biol. Educ. 1989, 23, 49-55. [CrossRef]

10. Flores, F.; Tovar, M.E.; Gallegos, L. Representation of the cell and its processes in high school students: An integrated view. Int. J. Sci. Educ. 2003, 25, 269-286. [CrossRef]

11. Hilge, C. Schülervorstellungen und Fachliche Vorstellungen zu Mikroorganismen und Mikrobiellen Prozessen: Ein Beitrag zur Didaktischen Rekonstruktion; Didaktisches Zentrum der Carl von Ossietzky Universität: Oldenburg, Germany, 1999.

12. Southard, K.M.; Espindola, M.R.; Zaepfel, S.D.; Bolger, M.S. Generative mechanistic explanation building in undergraduate molecular and cellular biology. Int. J. Sci. Educ. 2017, 39, 1795-1829. [CrossRef]

13. Dreyfus, A.; Jungwirth, E. The cell concept of 10th graders: Curricular expectations and reality. Int. J. Sci. Educ. 1988, 10, 221-229. [CrossRef]

14. Van Mil, M.H.W.; Postma, P.A.; Boerwinkel, D.J.; Klaassen, K.; Waarlo, A.J. Molecular Mechanistic Reasoning: Toward Bridging the Gap Between the Molecular and Cellular Levels in Life Science Education. Sci. Educ. 2016, 100, 517-585. [CrossRef]

15. Zamorra, M.C.; Guerra, M. Misconceptions about Cells. In Proceedings of the Third International Seminar on Misconceptions and Educational Strategies in Science and Mathematics, Ithaca, NY, USA, 1-4 August 1993.

16. Ummels, M.H.J.; Kamp, M.J.A.; de Kroon, H.; Boersma, K.T. Designing and Evaluating a Context-based Lesson Sequence Promoting Conceptual Coherence in Biology. J. Biol. Educ. 2014, 49, 38-52. [CrossRef]

17. Williams, M.; Montgomery, B.L.; Manokore, V. From Phenotype to Genotype: Exploring Middle School Students' Understanding of Genetic Inheritance in a Web-Based Environment. Am. Biol. Teach. 2012, 74, 35-40. [CrossRef] 
18. Marbach-Ad, G.; Stavy, R. Students' cellular and molecular explanations of genetic phenomena. J. Biol. Educ. 2010, 34, 200-205. [CrossRef]

19. Knippels, M.-C. Coping with the Abstract and Complex Nature of Genetics in Biology Education-The Yoyo Teaching and Learning Strategy; CD- $\beta$ Press: Utrecht, The Netherlands, 2002; Volume 43.

20. Knippels, M.-C.; Waarlo, A.J.; Boersma, K.T. Design criteria for learning and teaching genetics. J. Biol. Educ. 2005, 39, 108-112. [CrossRef]

21. Duncan, R.G.; Reiser, B.J. Reasoning across ontologically distinct levels: Students' understandings of molecular genetics. J. Res. Sci. Teach. 2007, 44, 938-959. [CrossRef]

22. Schwartz, R.; Brown, M.H. Understanding Photosynthesis and Cellular Respiration: Encouraging a View of Biological Nested Systems. In Multiple Representations in Biological Education; Treagust, D.F., Tsui, C.-Y., Eds.; Springer: Dordrecht, The Netherlands; Heidelberg, Germany; New York, NY, USA; London, UK, 2013; pp. 203-224. [CrossRef]

23. Songer, C.J.; Mintzes, J.J. Understanding Cellular Respiration-An Analysis of Conceptual Change in College Biology. J. Res. Sci. Teach. 1994, 31, 621-637. [CrossRef]

24. Anderson, C.W.; Sheldon, T.H.; Dubay, J. The Effects of Instruction on College Nonmajors Conceptions of Respiration and Photosynthesis. J. Res. Sci. Teach. 1990, 27, 761-776. [CrossRef]

25. Stavy, R.; Eisen, Y.; Yaakobi, D. How students aged 13-15 understand photosynthesis. Int. J. Sci. Educ. 1987, 9, 105-115. [CrossRef]

26. Lira, M.E.; Gardner, S.M. Structure-function relations in physiology education: Where's the mechanism? Adv. Physiol. Educ. 2017, 41, 270-278. [CrossRef]

27. Assaraf, O.B.-Z.; Dodick, J.; Tripto, J. High School Students' Understanding of the Human Body System. Res. Sci. Educ. 2013, 43, 33-56. [CrossRef]

28. Ebert-May, D.; Batzli, J.; Lim, H. Disciplinary research strategies for assessment of learning. Bioscience 2003, 53, 1221-1228. [CrossRef]

29. Düsing, K.; Asshoff, R.; Hammann, M. Students' conceptions of the carbon cycle: Identifying and interrelating components of the carbon cycle and tracing carbon atoms across the levels of biological organisation. J. Biol. Educ. 2018, 53, 110-125. [CrossRef]

30. Ferrari, M.; Chi, M.T.H. The nature of naive explanations of natural selection. Int. J. Sci. Educ. 1998, 20, 1231-1256. [CrossRef]

31. Shtulman, A. Qualitative differences between naive and scientific theories of evolution. Cogn. Psychol. 2006, 52, 170-194. [CrossRef] [PubMed]

32. Bishop, B.A.; Anderson, C.W. Student Conceptions of Natural-Selection and Its Role in Evolution. J. Res. Sci. Teach. 1990, 27, 415-427. [CrossRef]

33. Parker, J.M.; Anderson, C.W.; Heidemann, M.; Merrill, J.; Merritt, B.; Richmond, G.; Urban-lurain, M. Exploring Undergraduates' Understanding of Photosynthesis Using Diagnostic Question Clusters. CBE-Life Sci. Educ. 2012, 11, 47-57. [CrossRef] [PubMed]

34. Verhoeff, R.P.; Waarlo, A.J.; Boersma, K.T. Systems Modelling and the Development of Coherent Understanding of Cell Biology. Int. J. Sci. Educ. 2008, 30, 543-568. [CrossRef]

35. Eronen, M.I.; Brooks, D.S. Levels of Organization in Biology. Available online: https://plato.stanford.edu/ archives/spr2018/entries/levels-org-biology/ (accessed on 10 November 2018).

36. Rönnebeck, S.; Bernholt, S.; Ropohl, M. Searching for a common ground-A literature review of empirical research on scientific inquiry activities. Stud. Sci. Educ. 2016, 52, 161-197. [CrossRef]

37. Grene, M. Hierarchies in biology. Am. Sci. 1987, 75, 504-510.

38. Craver, C.F.; Bechtel, W. Top-down Causation Without Top-down Causes. Biol. Philos. 2006, 22, 547-563. [CrossRef]

39. MacMahon, J.A.; Phillips, D.L.; Robinson, J.V.; Schimpf, D.J. Levels of Biological Organization: An Organism-Centered Approach. BioScience 1978, 28, 700-704. [CrossRef] [PubMed]

40. Auger, P.; Lett, C. Integrative biology: Linking levels of organization. C. R. - Biol. 2003, 326, 517-522. [CrossRef]

41. Rowe, J.S. The Level-of-Integration Concept and Ecology. Ecology 1961, 42, 420-427. [CrossRef]

42. Findlay, S.D.; Thagard, P. How parts make up wholes. Front. Physiol. 2012, 3, 455. [CrossRef]

43. Okasha, S. Emergence, hierarchy and top-down causation in evolutionary biology. Interface Focus 2012, 2, 49-54. [CrossRef] 
44. Allen, T.F.H.; Hoekstra, T.W. The Confusion between Scale-Defined Levels and Conventional Levels of Organization in Ecology. J. Veg. Sci. 1990, 1, 5-12. [CrossRef]

45. Egler, F. Vegetation as an Object of study. Philos. Sci. 1942, 9, 245-260. [CrossRef]

46. Novikoff, A.B. The Concept of Integrative Levels and Biology. Science 1945, 101, 209-215. [CrossRef]

47. Wright, S. Genetics and the Hierarchy of Biological Sciences. Science 1959, 130, 959-965. [CrossRef]

48. Brooks, D.S.; Eronen, M.I. The significance of levels of organization for scientific research: A heuristic approach. Stud. Hist. Philos. Biol. Biomed. Sci. 2018, 68, 34-41. [CrossRef] [PubMed]

49. Wimsatt, W.C. Reductionism and its heuristics: Making methodological reductionism honest. Synthese 2006, 151, 445-475. [CrossRef]

50. Feibleman, J.K. Theory of Integrative Levels. Br. J. Philos. Sci. 1954, 5, 59-66. [CrossRef]

51. Knippels, M.-C.; Waarlo, A. Development, Uptake, and Wider Applicability of the Yo-yo Strategy in Biology Education Research: A Reappraisal. Educ. Sci. 2018, 8. [CrossRef]

52. Hmelo-Silver, C.E.; Marathe, S.; Liu, L. Fish Swim, Rocks Sit, and Lungs Breathe: Expert-Novice Understanding of Complex Systems. J. Learn. Sci. 2007, 16, 307-331. [CrossRef]

53. Sommer, C.; Harms, U. Biologische Systeme. Unterr. Biol. 2010, 360, 2-9.

54. Ruppert, W. Jo-Jo-Methode. In Biologie Methodik; Spörhase, U., Ruppert, W., Eds.; Cornelsen: Berlin, Germany, 2018; Volume 4.

55. Mayring, P. Qualitative Inhaltsanalyse. In Handbuch Qualitative Forschung in der Psychologie; Mey, G., Mruck, K., Eds.; Springer: Wiesbaden, Germany, 2010; pp. 601-613. [CrossRef]

56. Campbell, N.A.; Reece, J.B.; Urry, L.A.; Cain, M.; Wasserman, S.; Minorsky, P.V.; Jackson, R. (Eds.) Biology, 8th ed.; Pearson: San Francisco, CA, USA; Boston, MA, USA; New York, NY, USA, 2008.

57. Odum, E.; Barret, G. Fundamentals of Ecology; Thomson Brooks/Cole: Belmont, CA, USA, 2005; Volume 5.

58. Dawkins, R. The Extended Phenotype: The Gene as the Unit of Selection; Oxford University Press: New York, NY, USA, 1982.

59. Rosenberg, A. Darwinian Reductionism: Or, How to Stop Worrying and Love Molecular Biology; University of Chicago Press: Chicago, IL, USA, 2006.

60. Assaraf, O.B.-Z.; Orion, N. Development of system thinking skills in the context of earth system education. J. Res. Sci. Teach. 2005, 42, 518-560. [CrossRef]

61. Orion, N. An Earth Systems curriculum development model. In Global Sience Literacy; Mayer, V.J., Ed.; Kluwer Academic: Dordrecht, The Netherlands, 2002; pp. 159-168.

62. Mayer, V.J.; Armstrong, R.E. What every 17-year old should know about planet Earth: The report of a conference of educators and geoscientists. Sci. Educ. 1990, 74, 155-156. [CrossRef]

63. Brody, M.J. Student understanding of water and water resources: A review of the literature. In Proceedings of the Paper presented at the annual meeting of the American Educational Research Association, Atlanta, GA, USA, 12-16 April 1993.

64. Williams, M.; Debarger, A.H.; Montgomery, B.L.; Zhou, X.; Tate, E. Exploring middle school students' conceptions of the relationship between genetic inheritance and cell division. Sci. Educ. 2012, 96, 78-103. [CrossRef]

(C) 2019 by the authors. Licensee MDPI, Basel, Switzerland. This article is an open access article distributed under the terms and conditions of the Creative Commons Attribution (CC BY) license (http://creativecommons.org/licenses/by/4.0/). 